\title{
The Degradation of Nature and the Growth of Environmental Concern: Toward a Theory of the Capture and Limits of Ecological Value
}

\author{
Kirk S. Lawrence ${ }^{1}$
}

St. Joseph's College, New York, United States

Seth B. Abrutyn

University of Memphis, Tennessee, United States

\section{Abstract}

In this paper we overcome limitations of extant models of long-term social evolution by developing a formal theory that explains the emergence of environmental injustices and movements for environmental protection by incorporating the concept of ecological value, a value derived from the supply and quality of ecological services demanded by a society or group(s) within a society. The theory explains how intraand inter-societal imbalances of political and/or economic power are harnessed to capture distant ecological value in response to selection pressures resulting from reductions in the local level and/or quality of ecological services and in response to the growth of environmental concern. Opposing the continued capture are the same forces that generate it - ecological degradation and ecological concern-the dynamics of which shift along with the scale; as the forces move from the local to the global they lead to a bifurcation point at which either solutions for ecological sustainability are implemented or failure occurs in the form of ecological collapse. We close by considering the ramifications of this model in which the relative levels of these forces shape the future.

Keywords: environmental justice, environmentalism, political economy, theory, unequal ecological exchange

\section{Introduction}

The struggle for ecological justice reveals inequality in the benefits and costs of the human-environment relationship. While all societies degrade the quality of the environment to some degree as they extract, transform, and generate waste from resource use (cf. Chase-Dunn \& Hall, 2009; Chew, 2001), those

1 Corresponding author: klawrence@sjcny.edu. 
societies/groups/individuals with power can leverage it to experience more of the benefits of environmental use, creating "environmental privilege" (Park \& Pellow, 2013); conversely, less power often leads to fewer benefits and greater costs. For example, numerous studies over two decades in the United States have revealed that the locations of polluting sites are likely to be near concentrations of racial minorities and those in the lower class (Mohai et al., 2009; cf. Bullard, 2000; Downey, 2006; Elliott \& Pais, 2006; Grant et al., 2010; Pellow, 2002, 2004). On a global scale, the global North has used the global South as "trash dumps" (Faber, 2008) and ecologically unequal exchange has occurred as more-developed countries externalize the impacts of their consumption (such as deforestation due to beef and coffee) to less-developed countries (Jorgenson et al., 2009; cf. Bunker \& Ciccantell, 2005; Frey, 2009; Hornborg, 2001; Martínez-Alier, 1997, 2002; Moore, 2000a, 2000b, 2010; Rice, 2007, 2009; Roberts \& Parks, 2007, 2009). Generally speaking, ecological value is captured by groups with power advantages: upper classes, dominant racial or ethnic groups, and core states in the world-system.

In this paper, we examine the social evolution of ecological injustice and unequal ecological exchange through the development of a formal, general theory that explains their emergence and impact. The theory illustrates how power differences within and between societies have historically shaped, and been shaped by, three critical factors that are part of the exchange between our species and the environment: (1) the search for ecological value, undertaken to meet members' demands; (2) ecological injustice, stemming from inequalities in the realization of ecological value; and (3) the ideology of ecological concern, or the desire for ecological quality. These systemic processes, we argue, result in a capture of ecological value by the more powerful group. The capture of ecological value is an intergroup process that occurs as a solution to the pressures resulting from a reduction in the level and/or quality of ecological servicesthat is, ecological degradation - and because of the absence or inefficacy of sustainable solutions. The theory posits (1) ecological value as a function of the locally experienced supply and quality of ecological services; (2) the motivation to capture it as a function of selection pressures from both ecological degradation and demand for ecological services, and in response to the growth of the ideology of ecological concern; and (3) the ability to capture ecological value as a function of intra- and inter-societal imbalances of political and/or economic power. At the macro and global scales, the capture of ecological value is an emergent phenomenon; it appears as the polity and economy emerge and then strengthen as autonomous institutional spheres (Abrutyn, 2009, 2014b), reductions in ecological quality reach a threshold, and ecological concern becomes a widespread value. Opposing the continued capture are the same forces that generate it, the dynamics of which shift along with the social and geographic scale at which they operate. Hence, ecological value-seeking can act 
as motivation for ecological protection of and justice for the local individual, group, and/or society while simultaneously acting as motivation for distant degradation and injustice; with motivation turning to achievement if a favorable power imbalance exists. The way that these factors work in the future, we argue, will shape the possibilities for ecological sustainability at the global level.

Despite their importance, many extant theories of long-term social evolution suffer from omitting or underspecifying the role these factors play in the human-environment relationship and both human and non-human systems. For example, Chase-Dunn and Hall's (2009) "iteration model" includes "geographical/botanical/zoological capital" and environmental degradation as factors but does not include cultural factors such as conservation ideologies nor the manifestation of power as a variable in ecological exchange. Other models, like Chew's (2001, 2007, 2008), include power as a means to capital accumulation that - along with urbanization and population growth-leads to ecological degradation and periodic political/economic/demographic "Dark Ages"; however, Chew understates the impact the emergence of what he calls "ecological consciousness" has on reinterpreting the past as well as affecting the choices actors make in the present or future.

Alternatively, Moore (201la, 2011b) argues that successive ecological crises have existed over the longue durée of human evolution, resulting from the unnatural separation of social relations from the biophysical environment. Crises, then, grow parallel to the size and scale of separation. While we share Moore's (2011a, $2011 \mathrm{~b})$ perspective that a theory of human evolution must locate socio-ecological relations within evolutionary processes, he does not afford ecological concern much significance as a possible mediating or limiting factor in the evolution of those relations. Finally, ecological modernization theory suggests that technological innovations, efficiencies, and ecological concern, each reducing negative ecological impact, will occur together with development (cf. Mol et al., 2009). But there is limited evidence to support modernization theory's predictions (e.g., Dietz et al., 2012; Gonzalez, 2005); moreover, while modernization theory does offer an explanation of ecological concern it fails to include the effects of unequal development/environmental injustices and the emergence of ecological concern among less-developed societies.

This paper looks to supplement and build off these theories, by taking seriously the role of environmental ideologies, adding the capture of ecological value to the study of intra- and inter-societal processes, and delineating the dynamics of ecological value capture and the growth of ecological concern. In doing so, we posit a formal, general theory, built at an abstract level; that is, the model explains processes that are common within and between many societies but does not attempt to address instances of divergence and variation. Ultimately, this theory exposes the need for social change that addresses two key forces 
that can inhibit the possibilities for an ecologically sustainable and just future: inequalities in power and the localization of ecological concern. It is the unequal distribution of power within and between societies that allows for an ecological value capture to occur and the desire to protect the quality of the local over the global ecology that generates motivation to achieve this imbalance.

\section{A theory of the capture of ecological value}

Undergirding the emergence of the capture of ecological value are three very important forces creating the engine of change: population pressures, resource intensification, and environmental degradation. Building on the work of ChaseDunn and Hall (2009), population pressures are strains on a group resulting from the unmet resource demands of members of that group. A critical problem that emerges as populations grow in size is the increasing demand for resource production to meet consumption needs: more food, space, shelter, clothing, and other resources must be produced to meet the growing needs and demands of larger populations. Though several solutions are available to groups, research has shown that eventually circumscription (geographic, political, and/or social) limits mobility, and resource intensification-the increasing throughput of resources from an environment to meet the demands of the population-becomes the likely remedy. As resource intensification occurs, environmental degradation occurs: extraction of resources, exhaustion of soil, reduction of biodiversity, and the production of waste all reduce the quality of the environment (cf. Abrutyn \& Lawrence, 2010; Johnson \& Earle, 2000; Turner \& Maryanski, 2009).

To be sure, the "valences" at which population pressure, resource intensification, and environmental degradation become salient vary across time and place and are often dependent on many other factors, including the mode of productionbut these forces as the main drivers of change do not change. The classic "I=PAT" equation specifies environmental impact as a function of population size, affluence levels, and technology (Commoner, 1972; Ehrlich \& Holdren, 1971), but this can be expanded and nuanced. For example, Seccombe (1992) argues that population dynamics were linked to changing land availability and rights and associated norms of peasants regarding marriage that resulted in later marriages and fewer births during the transition from feudalism to capitalism. From Marx, we find the acceleration of resource demands associated with change from the production of goods for use to the production of goods for exchange reconceptualized as the treadmill(s) of production/accumulation/ consumption (cf. Foster, 2005). In his work on commodity frontiers, Moore (2000b, p. 416) reveals how the transition from smallholding, "subsistencesurplus" grain production to commodified sugar production by the Portuguese 
during the fifteenth century on the North Atlantic island of Madeira generated "ecological exhaustion" from an "environmentally destructive multiplier effect" (Moore, 2000b, pp. 412-413).

In this same work, Moore identifies an additional, and key, component of our theoretical model. Sugar production required a great deal of wood: fuel for the boilers, housing for labor, and ships for transport to markets. Local wood was utilized where available until supplies were exhausted. The continued demand for wood eventually led to the search for alternative sources, first destroying forests "adjacent to the cane fields [and later from] distant forests" (ibid., p. 420). Hence, resource extraction does not need to be limited to the local resource base, if and when resources can be extracted from other locations. To be sure, it becomes a matter of whether the means to foreign extraction are extant or not. If they are not, groups must innovate to extract resources, such as in the example of the triangular trade system premised on the New World colonies as resource suppliers (cf. Clark \& Foster, 2009; Moore, 2000a, 2010; Pointing, 2007, Chapter 9). Groups are motivated to innovation where environmental degradation has generated sufficient selection pressures, or pressures that challenge existing structural and cultural solutions to exigencies (Turner \& Maryanski, 2009; see also Cohen, 1977; Diamond, 2005; Pointing, 2007).

While specific adaptive responses vary in content and efficacy because of ecological, environmental, and sociocultural constraints, two general responses can be delineated: organizational and technological innovation. Organizational responses involve the emergence and coordination of horizontal and functional divisions of labor as well as vertical, hierarchical patterns of domination (Abrutyn, 2014b; Abrutyn \& Turner, 2011). Technological innovations are often harnessed as part of organizational responses. For example, in the premodern world, the emergence of temple- and then palace-economies facilitated the coordination of massive divisions of labor, the construction of complex public works - such as canals or irrigation systems - and the centralization of risk in trade and resource management (Earle, 2002; Yoffee, 2005). In the fifteenth-century transatlantic sugar trade, in addition to benefiting from the earlier advances in ship design and navigation (cf. Hugill, 1995), it took 20 years to create a production and export infrastructure. The organizational and technological innovations included "technical expertise and financing ... supplied by the Genoese, Portugal covered protection costs, and African slaves (imported by the Genoese and Portuguese)" (Moore, 2000b, p. 417).

Successful innovation not only contributes to the emergence of new selection pressures or the amplification of old ones, but also to increased political, military, and/or economic power - as was the case with the Genoese and Portuguese. The level of natural resources available to political actors also has important ramifications for power. A shortage of resources generates selection pressures 
for the emergence of an increasingly autonomous polity as an organizational innovation that can manage what little resources a group has while also finding ways to expand resource availability (Abrutyn, 2013, 2014a). More resources, however, make political goals and self-aggrandizement possible as surplus is centralized and power is monopolized. In short, population pressures and its consequences can get locked into a feedback loop that accelerates the evolutionary process, as power, technology, and the pressure for greater political organization intensify. Likewise, as political complexity grows, new logistical problems related to power inequities and legitimacy contribute to growing economic and legal complexity and, thereby, new selection pressures (Adams, 1966; Yoffee, 2005). Consequently, the expansion of power implies the use of more resources, the need for intensified production, and purposeful political policies aimed at population growth (Abrutyn \& Lawrence, 2010). For instance, Jorgenson and Clark (2009) find that a country's military spending increases its ecological footprint as it contributes to both the "treadmill of destruction" and the "treadmill of production."

As the levels of political, military, and economic power increase, the means to utilize that power - within and between societies - and the motivation to use this power grow concomitantly. As ambitions of and demands on a group/polity grow faster than a given populous and/or ecosystem can sustainably support, those with the means turn their attention outwards to potential sources of resources and solutions to selection pressures and the power and prestige that comes with them. We add the variable "motivation" to utilize power because it is not obvious that people in power simply create the means to conquer or ensnare outsiders. Rather, the means are created as reasons to exploit neighbors grow. Hence, as local ecological degradation causes available resources to decline, the motivation to seek replacement resources externally increases.

The motivation to seek distant resources may be better thought of as a capture of ecological value. The value is derived from ecological services (also called ecosystem services) that are "the many benefits - large and small, direct and indirect - that ecosystems provide to people. These consist of all the natural products and processes that contribute to human well-being, as well as the personal and social enjoyment derived from nature" (Landsberg et al., 2011, p. 1; see also Daily \& Matson, 2008; Emerson et al., 2012; Millennium Ecosystem Assessment, 2005; Trevors et al., 2006). While value is a complex concept that is historically contingent, ${ }^{2}$ part of the value of environmental use can occur

2 Value, as it relates to the environment, has a rich history as a contested concept that is beyond the scope of this paper; however, it should be noted that there are clear distinctions between instrumental and intrinsic value (Cobb, 1993) and between value as "homogenous social labor time" and exchange and use values (Burkett, 1999, pp. 81-82). These values are historically contingent, in the sense that they vary over time, space, and by mode of production, with the emergence of capitalism as the historical moment when value was an "abstraction from use value and nature" in order to facilitate accumulation (Burkett, 1999, p. 82; cf. 
through negative ecological impacts, such as the resort-style downhill ski industry (Park \& Pellow, 2013) or the exchange value generated in a situation in which forests are removed to create lumber for markets at the expense of a high-quality biosphere that provides ecosystem services that are sustainable, such as clean air and water; services can be aesthetic and/or ideological and, in that sense, value may occur from non-use - an "extra-human nature" (Burkett, 1999). Indeed, the sentiment that "nature" has intrinsic and/or spiritual value is found across time and place (Bell, 2012; Daniel et al., 2012; Hawken, 2007; de Steiguer, 2006). One attempt to place a monetary value on a variety of ecosystem services estimated their total biospheric value in a range of US\$16-54 trillion (Costanza et al., 1997). While there is a danger that monetization can lead to privatization, accumulation, or further injustices, mechanisms for the protection of ecological quality from a more holistic perspective are common, such as payments to landowners to maintain biodiversity (Pagiola et al., 2004).

Ecological degradation alters supply and demand curves for ecological services, reducing supply and increasing demand (Costanza et al., 1997). We posit that the increase in demand is both a reflection and an outcome of the growth of ecological concern, which can act as a powerful motivation for ecological value-seeking by interested individuals, organizations, and nation-states. Early examples of environmentalism appeared in the eighteenth and nineteenth centuries in the protection of colonies (Grove, 1995). Protests following Three Mile Island and Love Canal in the United States, Kenya's Green Belt Movement, Chico Mendes and the rubber tappers in Brazil, and the appearance and expansion of environmental and environmental justice movements as the scale of degradation increased in the post-World War II period are clear examples of the growth of ecological concern (Foster, 1999; McNeill, 2000; Pellow et al., 2001; Rudel et al., 2011).

With displaced degradation, ecological value - in addition to economic profitis captured by more powerful groups as they increase the level and quality of the ecosystem services they enjoy. But the use of power can also be in response to pressures from below for increases in ecological quality; specifically in the form of the ideology of ecological concern and in demands for ecological services that exceed current supply. We argue that ecological degradation triggers or amplifies these two factors, which tend to converge and become forces of social change.

Harvey, 1996; Moore, 2014). The value of ecosystem services could encompass all of these possible forms of value; e.g., a forest can represent instrumental value for the shelter it provides inhabitants, intrinsic value for people who feel love for the trees, value as homogenous social labor time for capitalists who are assessing the possibility of deforestation for the exchange value that will emerge as the lumber reaches the market, and use value from the oxygen generated. Of course, the different values can lead to either positive or negative outcomes for ecological sustainability. While monetizing ecological services has the potential to facilitate private accumulation, we believe that, if the services include the benefits to all species, it may offer the best solution in this historical moment; moreover, the growth of ecological concern, concern for both human and non-human rights to ecological equality, may demand that conceptualization of value. 
Given that humans prefer higher quality environments and the ecological services they provide for their mental and physical benefits, the environment is clearly a component in what is commonly called a standard of living. A decline in the real or perceived standard of living is an important motivating force for social action (Harris, 1977). And, similar to other forms of collective behavior, a certain level - or threshold - of concern typically needs to be met before that concern grows into pressure for change (Granovetter, 1978). Thus, the threshold would be reached when a significant proportion of the population - in size and/ or influence - experiences a real or perceived decline. We include the perception of a decline because the images of nature, the environment, and its effects are "refracted" through cultural lenses (Foster \& Holleman, 2012). When an actual or threatened reduction in local ecological quality from pollution or other forms of degradation creates a real or perceived decline in the standard of living, social movements often emerge to address the problems, including applying pressure on elites in the political economy to respond (cf. Polanyi, 1944 [2001]). The response can be for the improvement of local ecological quality through the institutionalization of sustainable use and a "steady-state economy" (Daly \& Townsend, 1993), but that solution is often subordinated to unsustainable economic growth (Foster et al., 2010; Pierce, 1992).

Another response to the demand for ecological services is to harness power for the capture of ecological value from distant sources; this can lead to conflict and imbalanced trade. In the modern world-system, scholars have studied the effects of imbalanced coercive power in systemic processes including colonization and trade. Core nations, or those in the most dominant trade positions (Frank, 2007), are able to extract natural resources and obtain cheap labor, either through the use of force or imbalanced exchanges, from semi-peripheral and peripheral nations (Chase-Dunn, 1998; Wallerstein, 1974). For example, typical unequal exchanges involve the transfer of economic and ecological value as low-value (but ecologically costly) raw materials flow from less-developed "extractive economies" in the periphery to developed countries in the core who profit from the transformation and consumption of the raw materials into highervalue products; some of which are exported back to the periphery (Bunker, 1985; Eisenmenger \& Giljum, 2007). Moreover, core nation-states and their multinational corporations use economic and political power to negotiate the terms of trade and foreign environmental, labor, and other regulations in their favor (Woods, 2006; see also Konisky, 2008; Stiglitz, 2007). Research has also uncovered "recursive exploitation": reforestation in the powerful core countries of the world-system, such as the United States and Japan, is linked to deforestation in the less powerful semi-periphery, such as Costa Rica and Indonesia, which in turn is tied to greater deforestation in the least powerful countries, such as Madagascar and Cote d'Ivoire (Burns et al., 2009; cf. Roberts et al., 2009). 
When the growth of ecological concern is limited to the local environment, a characteristic that can be traced back to our hunting and gathering origins (Moran, 2006, pp. 9-11), the capture of ecological value from others may meet with resistance primarily from ecological limits and opposition from groups who suffer the negative consequences. As previously mentioned, the demand of payments for ecological debt by groups in the global South is one example of contestation (e.g., Martínez-Alier, 1997). Other examples include movements in India against water use by Coca-Cola (Ciafone, 2012), in Brazil against ethanol production by Cargill (Via Campesina, 2010), and movements across Latin America against ecological injustices committed by powerful groups within the countries (Carruthers, 2008).

In recent years, the ideology of ecological concern has become globalized, and may constitute a worldwide value-orientation (Dunlap, 2006; Dunlap \& York, 2008) as it has been institutionalized as part of global governance (Biermann \& Pattberg, 2012; Chase-Dunn \& Hall, 2009; Frank et al., 2000; Lawrence, 2009; Schofer \& Hironaka, 2005). The expansion of concern acts as an emergent counter-force to attempts at ecological value capture. Sometimes the pressure emerges from local groups and "boomerangs" through international organizations to return back to the local political economy (Keck \& Sikkink, 1998). International certification programs, such as "dolphin safe" and organic labeling, are additional means by which ecological concern is globalized (Pattberg, 2012). Ecological concerns are also part of larger movements for global change, such as the anti-capitalist movement (Buttel \& Gould, 2004) and as "a movement of movements" as revealed at World Social Forums (Kaneshiro et al., 2012). Additionally, the proliferation of global environmental, nature-based, and environmental justice organizations, such as Greenpeace, World Wildlife Fund, and possibly thousands of others is evidence of other emerging global movements (Hawken, 2007).

It would be a mistake to ignore the pressure these groups and movements put on those in positions of power to effect change; if only as a means to reducing political and economic costs found in grievances and protests that threaten political elite's legitimacy or potential constituency (Martínez-Alier, 1997). As movements and organizations emerge and polities react to the pressures by creating environmental departments and regulations, a global ideology of ecological concern becomes a real force shaping the relationships between nation-states and patterns of legitimacy, albeit with inconsistent results thus far (Schofer \& Hironaka, 2005).

An additional limit emerges as systemic degradation, or the total amount of degradation across Earth's entire biosphere. It is accelerated both by the feedback loop discussed above and by the pursuit of ecological value as a solution. Climate change, for instance, is a form of degradation that has global effects regardless of the source of pollution. When system degradation threatens the system, as 
experienced locally in terms of declining quality of ecological services and opportunities, another source of pressure to act is placed on those in power. Systemic degradation can also contribute to spread the ideology of ecological concern, although with a lag effect because transportation/communication technologies, scientific knowledge, and the perception of a declining standard of living have not kept pace with the ability to degrade ecosystems and the entire biosphere; in addition, any ideology is always filtered through cultural lenses and must compete with other ideologies for prominence (Foster \& Holleman, 2012). Ultimately, a struggle ensues between forces of ecological degradation and protection.

\section{The formal theoretical model}

Our visual depiction of the full theoretical model containing the concepts and processes discussed is presented in Figure 1.

As we move from left to right across the model, the engine of change contains the population pressures and resource intensification that initially can generate an increase in resources. This leads to local ecological degradation, creating selection pressures for technological and organizational innovation as solutions. But unsustainable solutions lead to further degradation through the feedback loop in the engine of change. When effective solutions are not implemented, the likelihood of collapse, disintegration, and/or conquest increases.

The level and availability of natural resources will partially determine the level of political, military, and economic power that can be consolidated and, thereby, utilized against weaker groups or societies through the threat or use of force and/or the establishment of imbalanced trade relationships. But ecological quality declines as resource demands grow, leading to a decline in the real or perceived standard of living. As a threshold in the decline is reached, the affected relationships grow in number. First, there is a lag effect that eventually erodes the legitimacy and therefore the power of the ruling elite. The second effect is an increase in the motivation to use power to capture ecological value. Again, this refers to the elite's motivation to seek imbalanced relations externally, in this case to improve the real or perceived standard of living and reduce dissent in the populace. The third effect, the ideology of ecological concern, is represented by a dotted line because it is a relationship that has emerged in an organized form rather recently. As ecological concern gains traction and becomes a salient ideology in civil society, the potential for greater perception of declining standards of living due to ecological quality should also increase. Not only does this ideology offer people a framework for defining and understanding their local ecology, the presence and spread of such an ideology would likely produce 
associations or movements putting pressure on the polity and/or economy to take measures that improve ecological quality while also creating motivation for capturing ecological value from displaced degradation.

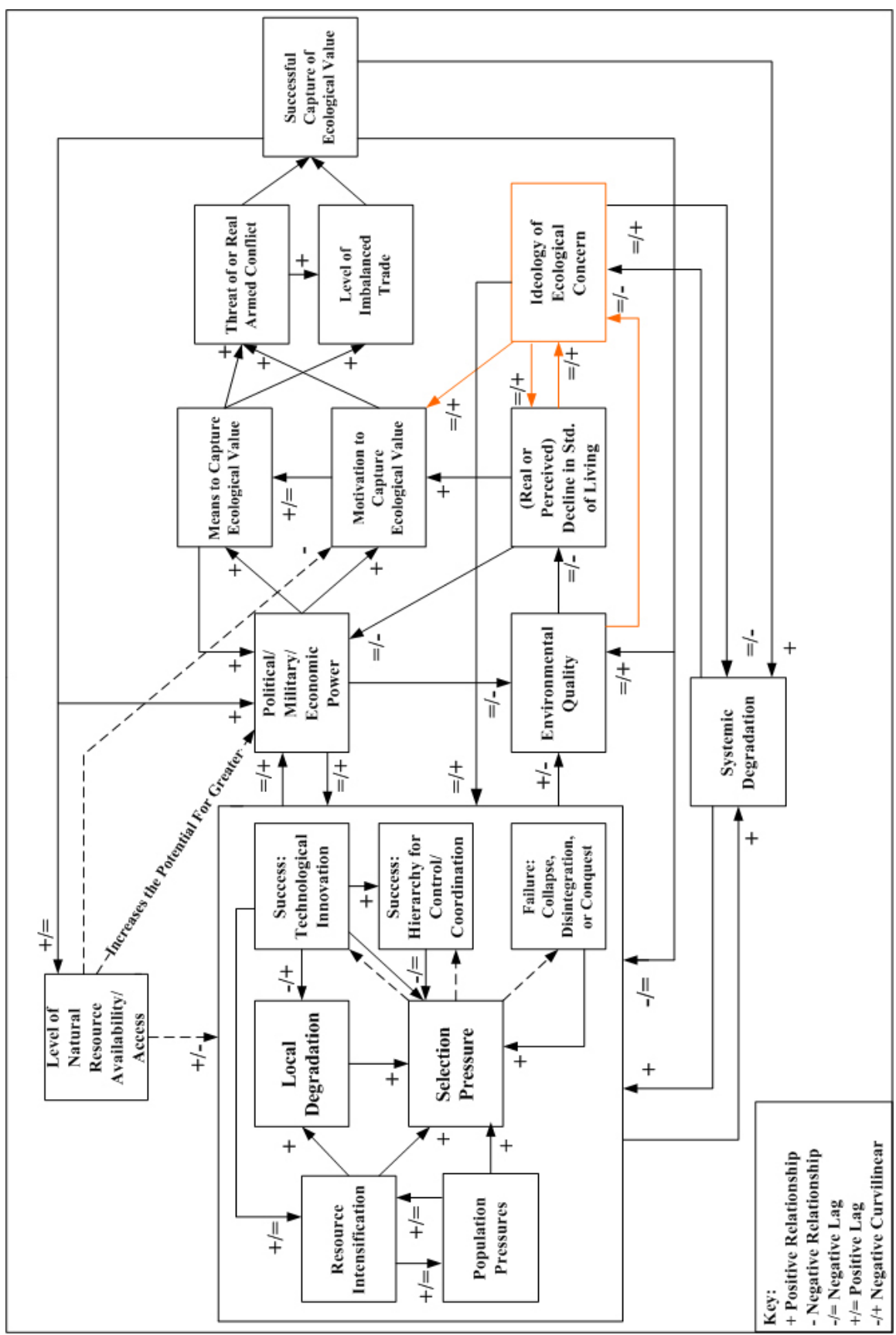

Figure 1: Theoretical model of the capture and limits of ecological value 
The successful capture of ecological value will both increase the local ecological quality and provide more resources for the more powerful group/society's production, consumption, and waste assimilation. But this leads to an increase in systemic degradation, which puts additional strain on all ecosystems but also generates an increase and global spreading of the ideology of ecological concern. The continued cycling of the processes leading to the capture of ecological value reaches an ultimate bifurcation point: (a) success - sustainable solutions are found; or (b) failure - the biosphere is degraded to the point that it can no longer support human societies.

\section{Discussion}

The theory presented here explains the macro-level dynamics applicable to the capture of ecological value. Any discussion of domestic and geopolitics, world-systems, or globalization must also contend with the fact that it is not just the traditional resource flows characterizing the unequal relationships between core-periphery or dominant-subordinate groups and societies; the displacement of environmental degradation is equally important and has a long history. While we have focused on macro-level dynamics, similar processes take place within societies as less powerful groups experience environmental injustice through exposure to a disproportionate share of the negative effects of intra-societal ecological degradation.

The displacement of degradation creates a paradox: the level of local and/or domestic resource consumption can seem sustainable, masking the impact on the environment in the system as a whole, and thus providing little incentive for truly sustainable living. This is not a new phenomenon in human social evolution as environmental degradation has been occurring for millennia. What is different, however, is the amount of resource use and waste production, currently requiring one-and-a-half Earths to assimilate (Global Footprint Network, 2010). There are more people using more resources in a finite biosphere. The types and degree of degradation have also increased due to technological innovation such as chemical production, nuclear fission, and fossil fuel-based manufacturing and transportation, while the effects of degradation are more difficult to contain in a particular area.

In response, environmental and environmental justice movements have led efforts to protect the biosphere in local and distant locations. Their work must be part of global movements toward innovation of sustainable means to live within the limits, however historically defined, necessary for ecosystems and the biosphere to provide ecological value for all inhabitants. As described by the theoretical model, and as demonstrated by societies in the past, failure results 
in ecological failure and the collapse of an environment's ability to support life. Due to the expansion of these processes to the global level, the Earth system is now in peril.

Important political, economic, and cultural ramifications emerge from this model. Local, NIMBYist protection of ecological value is unjust in the short term and unsustainable in the long term. The sense of what is "local" may change as knowledge of the complexity and interconnectedness of ecosystems spreads. The displacement of ecological degradation could reach an end when there are no longer any distant resources to exploit, which could occur as resources are exhausted and/or as ecological concern becomes universal, leaving no "others." An explicit recognition of the value of ecological services to the continuation of our species and of the connections between ours and other species that provide them is essential. But they cannot be privatized and sold to the highest bidder and/or for the benefit of some at the expense of others; that is, a continuation of capitalism's "cheap nature" strategy (Moore, 2014, p. 308). It must be a recognition and protection of ecological quality that all should share in. And the speed of the treadmills of production and consumption that have been reducing ecological quality cannot continue to expand.

This requires a much larger cultural change, away from ecologically destructive values and practices and toward a holistic ecological view. Beck's (2000) cosmopolitanism, in which a plurality of actors at multiple intra- and intersocietal levels strives for universal goals, is one guide. While imperfect, there is evidence that this has begun: The United Nations' conferences on sustainable development, Bolivia's "Law of the Rights of Mother Earth" (Ley de Derechos de la Madre Tierra) and the push for its global adoption (Global Alliance for the Rights of Nature, 2014), and, as previously mentioned, at World Social Forums. Contra modernization theory, ecological concern is not limited to developed countries. As Foster (2009) passionately argues, it may take a socialist revolution to generate the sweeping political, economic, and other cultural changes necessary to prevent local and global ecological destruction.

We do see the potential in a global ecosocialism for avoiding continued ecological decline and collapse. But, as Harvey (1996) asserts, a successful ecosocialist project must negotiate the multiple and changing temporal and social scales at which power and meaning reside; for example, there are "two senses of universality" in which universal inclusion must coexist with particularities in identity and practice (Harvey, 1996, p. 203). The particularities must, however, recognize the equality of all, both humans and the non-human world, in the sharing of ecological quality. It may be best, then, to return to Marx via Moore (2014, pp. 287, 304), who argued that human and extra-human natures, "historical natures," exist in a dialectal relationship - they can thrive or decline together. We believe that the emergence of ecological concern for human and 
extra-human natures as a universal ideology offers that promise. We hope that by explicating the social drivers of the capture of ecological value, the discussion and theory presented here can be part of that process.

\section{References}

Abrutyn, S. (2009). Towards a general theory of institutional autonomy. Sociological Theory, 27(4), 449-465.

Abrutyn, S. (2013). Political evolution, entrepreneurship, and autonomy: Causes and consequences of an "axial" moment. Research in Political Sociology, 21, 3-29.

Abrutyn, S. (2014a). Religious autonomy and religious entrepreneurship: An evolutionary-institutionalist's take on the axial age. Comparative Sociology, 13(2), 105-134.

Abrutyn, S. (2014b). Revisiting institutionalism in sociology: Putting the "institution" back in institutional analysis. New York: Routledge.

Abrutyn, S., \& Lawrence, K. (2010). From chiefdoms to states: Toward an integrative theory of the evolution of polity. Sociological Perspectives, 53(3), 419-442.

Abrutyn, S., \& Turner, J. H. (2011). The old institutionalism meets the new institutionalism. Sociological Perspectives, 54(3), 283-306.

Adams, R. M. (1966). The evolution of urban society: Early Mesopotamia and prehispanic Mexico. Chicago, IL: Aldine.

Beck, U. (2000). What is globalization? Cambridge: Polity Press.

Bell, M. M. (2012). An invitation to environmental sociology (4th ed.). Thousand Oaks, CA: Sage.

Biermann, F., \& Pattberg, P. (Eds.). (2012). Global environmental governance reconsidered. Cambridge, MA: The MIT Press.

Bullard, R. D. (2000). Dumping in Dixie: Race, class, and environmental quality (3rd ed.). Boulder, CO: Westview Press.

Bunker, S. G. (1985). Underdeveloping the Amazon: Extraction, unequal exchange, and the failure of the modern state. Urbana and Chicago, IL: University of Illinois Press.

Bunker, S. G., \& Ciccantell, P. S. (2005). Japan's economic ascent and its extraction of wealth from its raw materials peripheries. In P. S. Ciccantell, D. A. Smith 
\& G. Seidman (Eds.), Nature, raw materials, and political economy. Research in rural sociology and development (Vol. 10, pp. 187-207). San Diego, CA: Elsevier.

Burkett, P. (1999). Marx and nature: A red and green perspective. New York: St. Martin's Press.

Burns, T. J., Kick, E. L., \& Davis, B. L. (2009). A quantitative, cross-national study of deforestation in the late 20th century: A case of recursive exploitation. In A. Jorgenson \& E. Kick (eds), Globalization and the Environment (pp. 37-60). Chicago, IL: Haymarket Books.

Buttel, F. H., \& Gould, K. A. (2004). Global social movement(s) at the crossroads: Some observations on the trajectory of the anti-corporate globalization movement. Journal of World-Systems Research, 10(1), 37-66.

Carruthers, D. V. (Ed.). (2008). Environmental justice in Latin America: Problems, promise, and practice. Cambridge, MA: The MIT Press.

Chase-Dunn, C. (1998). Global formation: Structures of the world economy. Lanham, MD: Rowman \& Littlefield.

Chase-Dunn, C., \& Hall, T. D. (2009). Ecological degradation and the evolution of world-systems. In A. Jorgenson \& E. Kick (Eds.), Globalization and the Environment (pp. 231-252). Chicago, IL: Haymarket Books.

Chew, S. C. (2001). World ecological degradation: Accumulation, urbanization, and deforestation, 3000 B.C. - A.D. 2000. Lanham, MD: AltaMira Press.

Chew, S. C. (2007). The recurring Dark Ages: Ecological stress, climate changes, and system transformation. Lanham, MD: AltaMira Press.

Chew, S. C. (2008). Ecological futures: What history can teach us. Lanham, MD: AltaMira Press.

Ciafone, A. (2012). If "Thanda Matlab Coca-Cola" then "Cold Drink Means Toilet Cleaner": Environmentalism of the dispossessed in liberalizing India. International Labor and Working-Class History, 81, 114-135.

Clark, B., \& Foster, J. B. (2009). Ecological imperialism and the global metabolic rift: Unequal exchange and the guano/nitrates trade. International Journal of Comparative Sociology, 50(3-4), 311-334.

Cobb, J. (1993). Ecology, ethics, and theology. In H. E. Daly \& K. N. Townsend (Eds.), Valuing the earth: Economics, ecology, ethics (pp. 211-227). Cambridge, MA: The MIT Press. 
Cohen, M. N. (1977). The food crisis in prehistory: Overpopulation and the origins of agriculture. New Haven, CT: Yale University Press.

Commoner, B. (1972). The environmental cost of economic growth. In R. G. Ridker (Ed.), Population resources and the environment (pp. 339-363). Washington, DC: Government Printing Office.

Costanza, R., d'Arge, R., de Groot, R., Farber, S., Grasso, M., Hannon, B., ... van den Belt, M. (1997). The value of the world's ecosystem services and natural capital. Nature 387, 253-260.

Daily, G. C., \& Matson, P. A. (2008). Ecosystem services: From theory to implementation. PNAS, 105(28), 9455-9456.

Daly, H. E., \& Townsend, K. N. (1993). Valuing the earth: Economics, ecology, ethics. Cambridge, MA: The MIT Press.

Daniel, T. C., Muhar, A., Arnberger, A., Aznar, O., Boyd, J. W., Chan, K. M. A., ... von der Dunk, A. (2012). Contributions of cultural services to the ecosystem services agenda. PNAS, 109(23), 8812-8819.

Diamond, J. (2005). Collapse: How societies choose to fail or succeed. New York: Viking.

Dietz, T., Rosa, E. A., \& York, R. (2012). Environmentally efficient well-being: Is there a Kuznets curve? Applied Geography, 32, 21-28.

Downey, L. (2006). Environmental racial inequality in Detroit. Social Forces, $85(2), 771-796$.

Dunlap, R. E. (2006). Show us the data: The questionable empirical foundations of "the death of environmentalism" thesis. Organization \& Behavior, 19(1), 88-102.

Dunlap, R. E., \& York, R. (2008). The globalization of environmental concern and the limits of the postmaterialist values explanation: Evidence from four multinational surveys. The Sociological Quarterly, 49(3), 529-563.

Earle, T. (2002). Bronze Age economics: The beginnings of political economies. Boulder, CO: Westview Press.

Ehrlich, P. R., \& Holdren, J. P. (1971). Impact of population growth. Science, 171(3977), 1212-1217. 
Eisenmenger, N., \& Giljum, S. (2007). Evidence from societal metabolism studies for ecological unequal trade. In A. Hornborg \& C. Crumley (Eds.), The world system and the earth system: Global socioenvironmental change and sustainability since the Neolithic (pp. 288-302). Walnut Creek, CA: Left Coast Press.

Elliott, J. R., \& Pais, J. (2006). Race, class, and Hurricane Katrina: Social differences in human responses to disaster. Social Science Research, 35(2), 295-321.

Emerson, J. W., Hsu, A., Levy, M. A., de Sherbinin, A., Mara, V., Esty, D. C. \& Jaiteh, M. (2012). Environmental performance index and pilot trend environmental performance index. New Haven, CT: Yale Center for Environmental Law and Policy.

Faber, D. (2008). Capitalizing on environmental injustice: The polluter-industrial complex in the age of globalization. Lanham, MD: Rowman \& Littlefield.

Foster, J. B. (1999). The vulnerable planet: A short economic history of the environment. New York: Monthly Review Press.

Foster, J. B. (2005). The treadmill of accumulation: Schnaiberg's environment and Marxian political economy. Organization Environment, 18(1), 7-18.

Foster, J. B. (2009). The ecological revolution: Making peace with the planet. New York: Monthly Review Press.

Foster, J. B., Clark, B., \& York, R. (2010). The ecological rift: Capitalism's war on the earth. New York: Monthly Review Press.

Foster, J. B., \& Holleman, H. (2012). Weber and the environment: Classical foundations for a post-exemptionalist sociology. American Journal of Sociology, 117(6), 1625-1673.

Frank, A. G. (2007). Entropy generation and displacement: The nineteenthcentury multilateral network of world trade. In A. Hornborg \& C. Crumley (Eds.), The world system and the earth system: Global socioenvironmental change and sustainability since the Neolithic (pp. 303-316). Walnut Creek, CA: Left Coast Press.

Frank, D. J., Hironaka, A., \& Schofer, E. (2000). The nation state and the natural environment, 1900-1995. American Sociological Review, 6(5), 96-116.

Frey, R. S. (2009). The flow of hazardous exports in the world-system: The case of the maquiladora centers of northern Mexico. In A. Jorgenson \& E. Kick (Eds.), Globalization and the environment (pp. 133-139). Chicago, IL: Haymarket Books. 
Global Alliance for the Rights of Nature. (2014). What is rights of nature? Retrieved from http://therightsofnature.org/what-is-rights-of-nature/.

Global Footprint Network. (2010). World footprint. Retrieved from http://www. footprintnetwork.org/en/index.php/GFN/page/world_footprint/.

Gonzalez, G. A. (2005). The politics of air pollution: Urban growth, ecological modernization, and symbolic inclusion. Albany: SUNY Press.

Granovetter, M. (1978). Threshold models of collective behavior. American Journal of Sociology, 83(6), 1420-1443.

Grant, D., Trautner, M. N., Downey, L., \& Thiebaud, L. (2010). Bringing the polluters back in: Environmental inequality and the organization of chemical production. American Sociological Review, 75(4), 479-504.

Grove, R. H. (1995). Green imperialism: Colonial expansion, tropical island Edens and the origin of environmentalism. New York: Cambridge University Press.

Harris, M. (1977). Cannibals and kings: The origins of cultures. New York: Vintage Books.

Harvey, D. (1996). Justice, nature, and the geography of difference. Cambridge, MA: Blackwell Publishers.

Hawken, P. (2007). Blessed unrest: How the largest movement came into being and why no one saw it coming. New York: Penguin.

Hornborg, A. (2001). The power of the machine: Global inequalities of economy, technology, and environment. Walnut Creek, CA: AltaMira Press.

Hugill, P. J. (1995). World trade since 1431: Geography, technology, and capitalism. Baltimore, MD: Johns Hopkins University Press.

Johnson, A. W., \& Earle, T. (2000). The evolution of human societies: From foraging groups to agrarian state. Palo Alto, CA: Stanford University Press.

Jorgenson, A. K., Austin, K., \& Dick, C. (2009). Ecologically unequal exchange and the resource consumption/environmental degradation paradox: A panel study of less-developed countries, 1970-2000. International Journal of Comparative Sociology, 50(3-4), 263-284.

Jorgenson, A. K., \& Clark, B. (2009). The economy, military, and ecologically unequal exchange relationships in comparative perspective: A panel study of the ecological footprints of nations, 1975-2000. Social Problems, 56(4), 621-646. 
Kaneshiro, M., Lawrence, K. S., \& Chase-Dunn, C. (2012). Global environmentalists and their movements at the world social forums. In J. Smith, S. Byrd, E. Reese \& E. Smythe (Eds.), Handbook on world social forum activism (pp. 186-205). Boulder, CO: Paradigm.

Keck, M., \& Sikkink, K. (1998). Activists beyond borders: Trans-national advocacy networks in international politics. Ithaca, NY: Cornell University Press.

Konisky, D. M. (2008). Regulator attitudes and the environmental race to the bottom argument. Journal of Public Administration Research and Theory, 18(2), 321-344.

Landsberg, F., Ozment, S., Stickler, M., Henninger, N., Treweek, J., Venn, O., \& Mock, G. (2011). Ecosystem services review for impact assessment: Introduction and guide to scoping. WRI Working Paper. Washington, DC: World Resources Institute.

Lawrence, K. S. (2009). Toward a democratic and collectively rational global commonwealth: Semi-peripheral transformation in a post-peak worldsystem. In O. Worth \& P. Moore (Eds.), Globalization and the "new" semiperipheries (pp. 198-212). New York: Palgrave Macmillan.

Martínez-Alier, J. (1997). Environmental justice (local and global). Capitalism, nature, socialism, 8(1), 91-107.

Martínez-Alier, J. (2002). The environmentalism of the poor: A study of ecological conflicts and valuation. Cheltenham, UK: Edward Elgar.

McNeill, J. R. (2000). Something new under the sun: An environmental history of the twentieth-century world. New York: W. W. Norton \& Company.

Millennium Ecosystem Assessment. (2005). Ecosystems and human well-being: Synthesis. Washington, DC: Island Press.

Mohai, P., Pellow, D., \& Roberts, J. T. (2009). Environmental justice. Annual Review of Environment and Resources, 34, 405-430.

Mol, A. P. J., Sonnenfeld, D. A., \& Spaargaren, G. (Eds.). (2009). The ecological modernization reader: Environmental reform in theory and practice. London: Routledge.

Moore, J. W. (2000a). Environmental crises and the metabolic rift in worldhistorical perspective. Organization \& Environment, 13(2), 123-157.

Moore, J. W. (2000b). Sugar and the expansion of the early modern world-economy: Commodity frontiers, ecological transformation, and industrialization. Review (Fernand Braudel Center), 23(3), 409-433. 
Moore, J. W. (2010). "Amsterdam is standing on Norway", part I: The alchemy of capital, empire, and nature in the diaspora of silver, 1545-1648. Journal of Agrarian Change, 10(1), 33-68.

Moore, J. W. (201 la). Ecology, capital, and the nature of our times: Accumulation \& crisis in the capitalist world-ecology. The Journal of World-Systems Research, 17(1), 108-147.

Moore, J. W. (2011b). Transcending the metabolic rift: A theory of crises in the capitalist world ecology. Journal of Peasant Studies, 38(1), 1-46.

Moore, J. W. (2014). The end of cheap nature. Or how I learned to stop worrying about "the" environment and love the crisis of capitalism. In C. Suter \& C. Chase-Dunn (Eds.), Structures of the world political economy and the future of global conflict and cooperation (pp. 285-314). Berlin: LIT.

Moran, E. F. (2006). People and nature: An introduction to human ecological relations. Malden, MA: Blackwell.

Pagiola, S., Agostini, P., Gobbi, J., de Haan, C., Ibrahim, M., Murgueitio, E., ... Ruiz, J. P. (2004). Paying for biodiversity conservation services in agricultural landscapes. The World Bank Environment Department Paper No. 96. Washington, DC: The World Bank.

Park, L. S-H., \& Pellow, D. N. (2013). The slums of Aspen. New York: New York University Press.

Pattberg, P. (2012). Transnational environmental regimes. In F. Biermann \& P. Pattberg (Eds.), Global environmental governance reconsidered (pp. 97-120). Cambridge, MA: The MIT Press.

Pellow, D. N. (2002). Garbage wars: The struggle for environmental justice in Chicago. Cambridge, MA: The MIT Press.

Pellow, D. N. (2004). The politics of illegal dumping. Qualitative Sociology, 27(4), $511-525$.

Pellow, D. N., Weinberg, A., \& Schnaiberg, A. (2001). The environmental justice movement: Equitable allocation of costs and benefits of environmental management outcomes. Social Justice Research, 14(4), 423-439.

Pierce, J. T. (1992). Progress and the biosphere: The dialectics of sustainable development. The Canadian Geographer, 36(4), 306-320.

Pointing, C. (2007). A new green history of the world: The environment and the collapse of great civilizations. New York: Penguin Group. 
Polanyi, K. (1944 [2001]). The great transformation: The political and economic origins of our time (2nd ed.). Boston, MA: Beacon Press.

Rice, J. (2007). Ecological unequal exchange: Consumption, equity, and unsustainable structural relationships within the global economy. International Journal of Comparative Sociology, 48(1), 43-72.

Rice, J. (2009). Ecologically unequal exchange, ecological debt, and climate justice. International Journal of Comparative Sociology, 50(3-4), 385.

Roberts, J. T., Grimes, P., \& Manale, J. (2009). Social roots of global environmental change: A world-systems analysis of carbon dioxide emissions. In A. Jorgenson \& E. Kick (Eds.), Globalization and the environment (pp. 79117). Chicago, IL: Haymarket Books.

Roberts, J. T., \& Parks, B. (2007). A climate of injustice: Global inequality, northsouth politics, and climate policy. Cambridge, MA: MIT Press.

Roberts, J. T., \& Parks, B. (2009). Ecologically unequal exchange, ecological debt, and climate justice: The history and implications of three related ideas for a new social movement. International Journal of Comparative Sociology, 50(3-4), 385-409.

Rudel, T. K., Roberts, J. T., \& Carmin, J. 2011. Political economy of the environment. Annual Review of Sociology, 37, 221-238.

Schofer, E., \& Hironaka, A. (2005). The effects of world society on environmental protection outcomes. Social Forces, 84(1), 25-47.

Seccombe, W. (1992). A millennium of family change: Feudalism to capitalism in northwestern Europe. New York: Verso.

de Steiguer, J. E. (2006). The origins of modern environmental thought. Tucson, AZ: The University of Arizona Press.

Stiglitz, J. E. (2007). Making globalization work. New York: W. W. Norton.

Trevors, J. T., Kevan, P. G., \& Saier, M. H., Jr., (2006). Biosphere quality index (BQI). Water, Air, \& Soil Pollution, 173(1-4), 1-3.

Turner, J. H., \& Maryanski, A. (2009). On the origins of societies by natural selection. Boulder, CO: Paradigm.

Via Campesina. (2010). Some brief news reports from direct action-based resistance around the world: Brazil, UK, Germany, and the Philippines. In Abramksy, K. (Ed.), Sparking a worldwide energy revolution: Social struggles in the transition to a post-petrol world (pp. 482-485). Oakland, CA: AK Press. 
Wallerstein, I. (1974). The modern world-system: Capitalist agriculture and the origins of the European world-economy in the sixteenth century. New York: Academic Press.

Woods, N. D. (2006). Interstate competition and environmental regulation: A test of the race to the bottom thesis. Social Science Quarterly, 87(1), 174-189.

Yoffee, N. (2005). Myths of the archaic state: Evolution of the earliest cities, states, and civilizations. New York: Cambridge University Press. 
This text taken from Human Ecology Review Volume 21, Number 1, 2015, published 2015 by ANU Press, The Australian National University, Canberra, Australia. 